\title{
両側声帯麻瘏の治療方針に関する一考察
}

\author{
渋沢 三伸・羽成 敬一*
}

\section{Laryngeal Findings and the Purpose of Treatment of Bilateral Vocal Cord Paralysis}

\author{
Mitsunobu Shibusawa \\ (Tokyo Medical and Dental University) \\ Keiich Hanari \\ (Toride Kyodo Hospital)
}

As in the case of unilateral vocal cord paralysis, the clinical symptoms of bilateral vocal cord paralysis differ according to the position in which vocal cords are fixed and the shape of the vocal cords themselves.

In most cases of unilateral vocal cord paralysis, disphonia is the main problem. On the other hand, problems associated with respiration and swallowing are equally important to those of phonation in cases of bilateral vocal cord paralysis.

Patients with bilateral vocal cord paralysis are classified into two groups. One group consists of patients whose vocal cords are both fixed in the midline position; the other group of those whose vocal cords are in other positions. Both groups are subdivided into two groups according to whether their vocal cords show atrophy (bowing) or not.

In patients with bilateral vocal cord paralysis, the clinical symptoms are qualitatively different depending on the fixed vocal cords' position. Therefore, it is important for both patients and doctors to define the purpose of treatment; in other words, to define which is to be cured, dyspnea or dysphonia.

Key words: bilateral vocal cord paralysis, treatment of dyspnea, treatment of dysphonia

はじめに

両側の声带運動障害は比較的稀な喉頭の一病 態である。片側声帯（または反回神経）麻痺 (以下，片側麻痺）飞対応させて両側声帯（また は反回神経）麻痺（以下，両側麻㾝）という用 語が用いられている. 麻痺の症状としては, 片 側麻痺では早期の誤暪の問題を除くとほとんど
発声障害に限られるが，両側麻痺では呼吸，発 声および鯂下障害(誤曣)のいずれも主要な問題 となってくるために，その治療に難渋する場合 が多く，耳鼻咽喉科医を悩ませるやっかいな病 態である. 呼吸困難は直接生命にかかわる問題 であるため，その治療についての報告は多い， 一方, 両側麻痺によって生じた発声障害は極め 
て高度であるにあかかわらず，その対策につい て述べた報告は少ない，著者らは最近経験した 症例をむとに，両側麻痺に対する治療上の問題 を再検討した．また治療の現状について若干の 文献的考察を行ったので報告する.

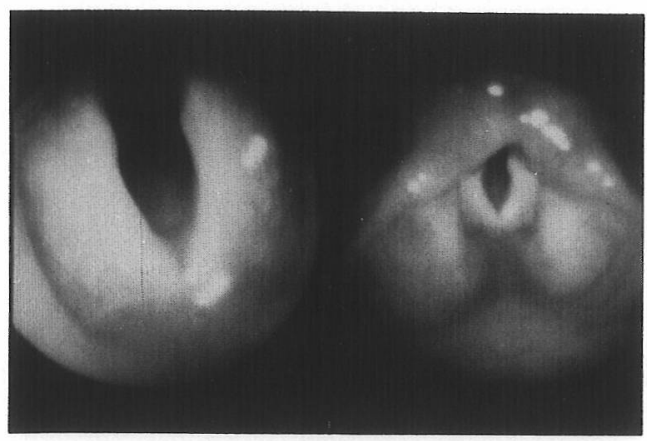

a

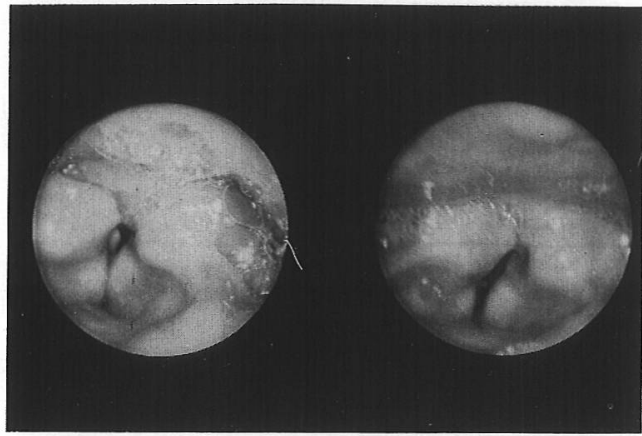

b

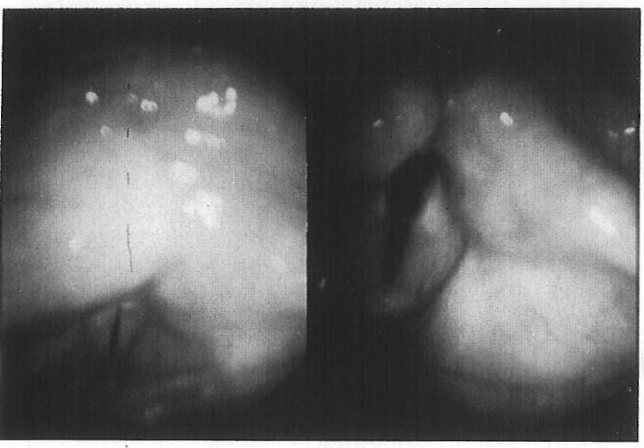

d
症例

症例 1. H. I. 40歳, 女性, 主婦.

主訴 : 㖽声 (失声).

現病歴：1986年12月19日，甲状腺腫瘍のため 他院にて甲状腺全摘出術および両側頸部郭清術

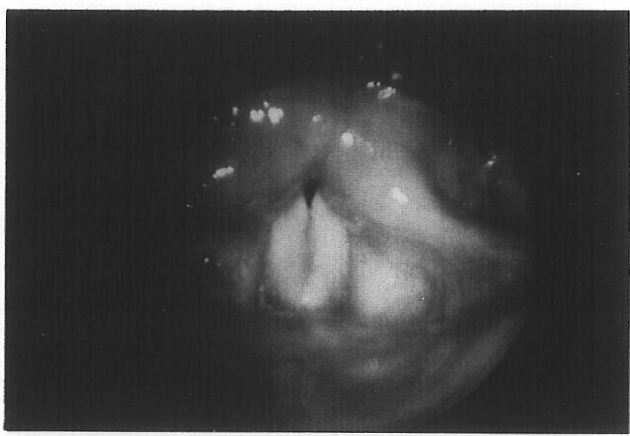

$a^{\prime}$
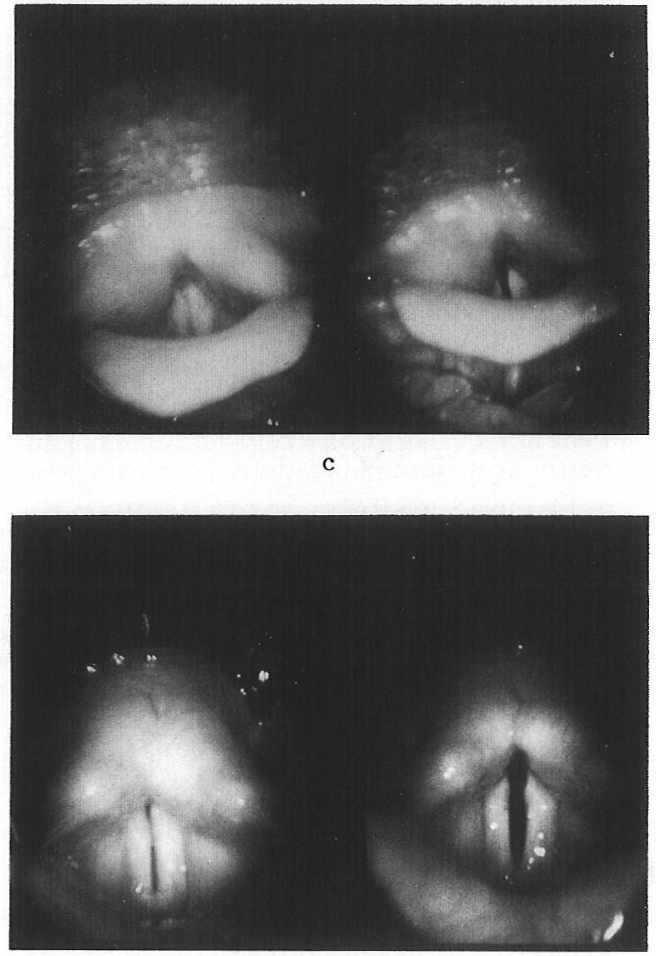

e

図 1

a : 症例 1 . 治療前.

$\mathrm{a}^{\prime}$ : 症例 1. 二回目のシリコン注入後 (1989.5.22).

$\mathrm{b}$ : 症例 2 . 一回目の入院時.

d : 症例 4 .

c : 症例 3 . 気管切開の一週間後.

$\mathrm{e}:$ 症例 5 .

$\mathrm{a} \sim \mathrm{e}$ のいずれあ左が発声時で右が最大開大時の喉頭像である. 
を受けたが，術後失声状態となった．1987年 5 月28日，当科を初診し，両側麻疩と診断された。

初診時の喉頭所見 : 両側の声帯がやや外転し た状態で固定しており，弓状変化をともなって いた。 また呼吸，発声および咳による運動を全 く認めなかった（図1-a).

治療と経過：本症例の治療と症状の経過を， 表 1 亿示す.

症例 2. A. T. 65歳, 男性, 農業.

主訴：呼吸困難.

現病歴：1988年 9 月頃から嗄声があった. 10 月11日，取手協同病院耳鼻科を初診し，両側麻 痺と診断された。労作時, 深吸気時の喘鳴はあ ったが呼吸困難の訴えはなかったので経過観察 となった，その後，夜間に強い呼吸困難が出現 するようになったため1988年11月 9 日，同院へ 精査を目的として入院した，入院中は睡眠時の 喘鳴はあったが，呼吸困難のために覚醒するこ とはなく, 呼吸困難が増悪する傾向がなかった

表 1 症例 1 の治療と経過. 有声音とは, わずかであ るが発声時声帯振動が得られたという意味であ る。

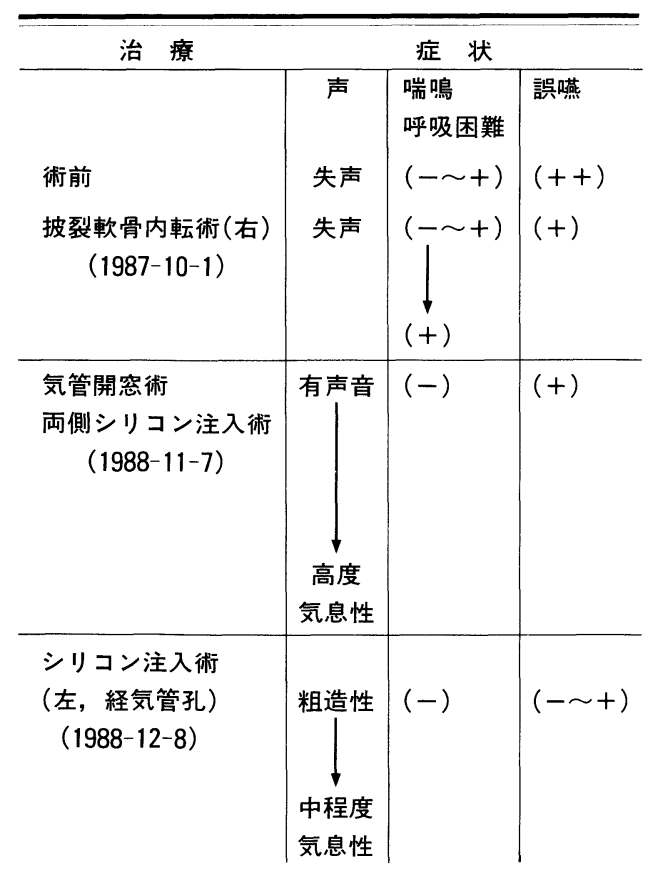

ため退院した。しかし12月16日，呼吸困難が急 激に強くなったため再入院となった。翌日緊急 気管切開が行なわれた。

初診時の喉頭所見：両側の声帯がほぼ正中位 に固定していた。ただし両側仮声帯がつよく膨 隆していたため，声帯の詳細な状態は不明であ った，披裂部にはわずかな運動性を認めた（図 1-b ）．再入院時にはこのわずかな運動性も消 失していた。

治療と経過：1989年 1 月31日，全身麻酔下に 喉頭截開による右披裂軟骨摘出術および声帯外 側毫引固定術1)を行った。 2 月29日，気管孔を 閉鎖し，3 月 4 日退院した。麻舫の原因は不明 である.

症例 3. K. O. 65歳, 女性, 主婦.

主訴：呼吸困難.

現病歷：1989年 4 月 3 日，他科にて甲状腺左 葉切除術をうけた。術後, 呼吸困難と誤與が出 現したため 4 月 5 日に当科を初診した。 4 月 6 日，気管切開術が行なわれた。

初診時の喉頭所見：両側の声帯が正中位に固 定していたが，声門部にわずかに間隙を認めた (図 $1-\mathrm{c}$ ).

治療之経過： 5 月 2 日, 気管孔にシリコン $\mathrm{T}$ チューブを挿入した。はじめは気管孔を閉鎖す ると呼吸困難がつよいため，栓を解放したまま 様子をみていたが，声門間隙の変化に応じて栓 をする時間を徐々に延長し，現在は夜間のみ解 放している.

症例 4. T. T. 64歳, 女性, 主婦。

主訴：嗄声.

現病歴：1988年10月 3 日，他科にて甲状腺全 摘出術をうけた。直後より失声状態となった。

10月13日に当科を初診した。呼吸困難はなか ったので退院した。

初診時の喉頭所見：両側の声带がやや外転し た状態でほぼ固定していたが，声帯，披裂部と あにわずかな運動性を認めた。

経過：10月20日頃から声帯固定がつよくなり， 11月10日には両側ともわずかな声門間隙を残し 
た状態で完全に固定した。同時に夜間の呼吸困 難, 喘鳴が出現した. 声は失声状態から極めて 高度な気息性嗄声に変化した。11月20日より歩 行時の呼吸困難, 安静時の喘息が出現したため 11月24日，当院耳鼻科に入院した。 入院時には 呼吸困難がやや改善するとともに声帯運動むわ ずかながら認められるようになったため，その まま経過観察している，現在の喉頭所見（図 1 - d) では運動域はかなり狭いものの発声時の 声門閉銷は良好で，発声持続時間が 3 秒を超え るようになった。

症例 5. C. N. 49歳, 女性, 主婦.

主訴 : 労作時呼吸困難, 嗄声

現病歴：1988年10月頃から嗄声と喘鳴が出現 し，徐々に増強してきたため他院内科を受診し たところ喘息の疑いと診断され治療をうけてい た。 12月21日，小川赤十字病院耳鼻科受䛦し両 側麻瘏と診断された。1989年 1 月 24 日，精査を 目的として当院耳鼻科を受診した.

初診時の喉頭所見: 声帯, 披裂部ともにわず かながら運動性を認めた。声帯突起間の最大幅 は $2 \mathrm{~mm}$ 程度と推定された。発声時には声門が ほぼ閉鎖された（図 1-e).

経過：精査目的で1989年 2 月 4 日，当院耳鼻 科へ入院した。喉頭を刺激すると反射性に呼吸 困難が増強するととがあったが，気管切開を行 うには至らなかった。そ後李喉頭所見に大き な変化はなく，現在経過観察中である，麻疩の 原因は不明である。

\section{考察}

1. 両側麻㽻の喉頭像と治療方針

片側麻痺の場合と同様に両側麻痺の場合も, 声帯が固定されている位置や, 声帯そのものの 変化によって症状が異なる.ただし片側麻痺で は，ほとんどの症例で発声が主要な問題となる のに対して，両側麻痺では呼吸，発声および 噁下に関する問題がいずれも重要となる。そし てその症状は声帯の固定位によってある程度規 定されてくる. 両側麻痺の喉頭所見は声帯の固 定位により二型に大別できる（図 2 )。両側声
帯ともに正中位固定の場合を type 1 (正中位固 定型)，どちらかの，あるいは両側の声帯が正 中より外側で固定されている場合を type 2 (非 正中位固定型）の麻痺と呼ぶことにする. type 1, 2 ともに声帯の弓状変化 (bowing) を伴うか 否かで $a, b$ の亜型に分類される. ただし声帯 位抒よび声帯の形状ともに非発声時の状態によ って分類する。したがってどちらか一方あるい は両側の声帯に，発声動作にとあなうわずかな 運動性を認める場合には，たとえば type 1a（右 声帯にわずかな外転運動あり）のように記載す る. この分類はあくまで喉頭の内視鏡的所見に よるあので, 筋電図学的あるいは病理学的な所 見にもとづく分類とは無関係である，また本稿 では完全麻痺, 不完全麻痺という用語は使わな いことにする．用語の定義があいまいだからで ある。

一般的に type 1a では気道閉塞による呼吸困 難が主症状となり，緊急気管切開を要すること も少なくない. type 1b は呼吸機能の状態が症 状に強い影響を及ぼす喉頭像であり, 症状から は type $1 \mathrm{a}$ と $2 \mathrm{a}, \mathrm{b}$ の中間型と考えられる. 呼吸 困難, 嗄声および誤曣がいずれも主訴となりう

る. type $2 \mathrm{a}, \mathrm{b}$ では嗄声および誤嚥が主症状と なるが， b がより高度な症状を示す，嗄声は極 めて高度で多くの場合, 失声状態である。いず れの場合でも，たとえわずかでも声带運動が保

\section{呼吸困難}
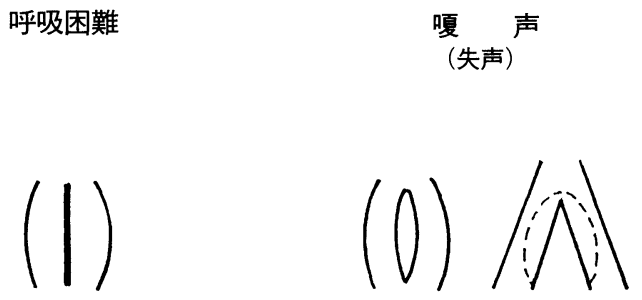

type $1, a$

type 1,b type2,a,b

図 2 両側麻㽻の喉頭像之症状の関係. type $1 \mathrm{~b}$ では 症例によっては呼吸困難を伴うことがある. 誤 曣は喉頭像にかかわりなく多かれ少なかれ認め られる。 
存されていれば，重症度や緊急性はずっと少な くなる。初診時の所見では，症例 1 は type $2 b$, 症例 2 は type $1 \mathrm{a}$ (わずかな外転運動あり), 症例 3 は type 1a, 症例 4,5 は type $2 \mathrm{a}$ (わずかな内 転運動あり）に相当した。

両側麻痺の場合は喉頭像のちがいにより症状 に質的差が生じるため，治療に際しては，その 目的を明確にするととが重要である。基本的に は, type 1a では声門開大術, type $2 \mathrm{a}, \mathrm{b}$ では声 帯内方移動術という図式がなりたつ. type 1b
では嗄声は必発であるが，呼吸困難や誤嚥の程 度は症例毎に異なるので, 症状の程度と呼吸機 能を慎重に評価したうえで治療方針を決定すべ きである。また声帯内方移動術は，術前に失声 状態であり，かつ患者が発声機能の改善を強く 望む場合にのみ適応される。ささらに永久気管孔 造設が必要となる場合があるととについての説 明あ必須である。声門開大術, 声帯内方移動術 ともに多くの術式が考案されているが，具体的 な術式の選択に関する考察は他稿に譲りたい.
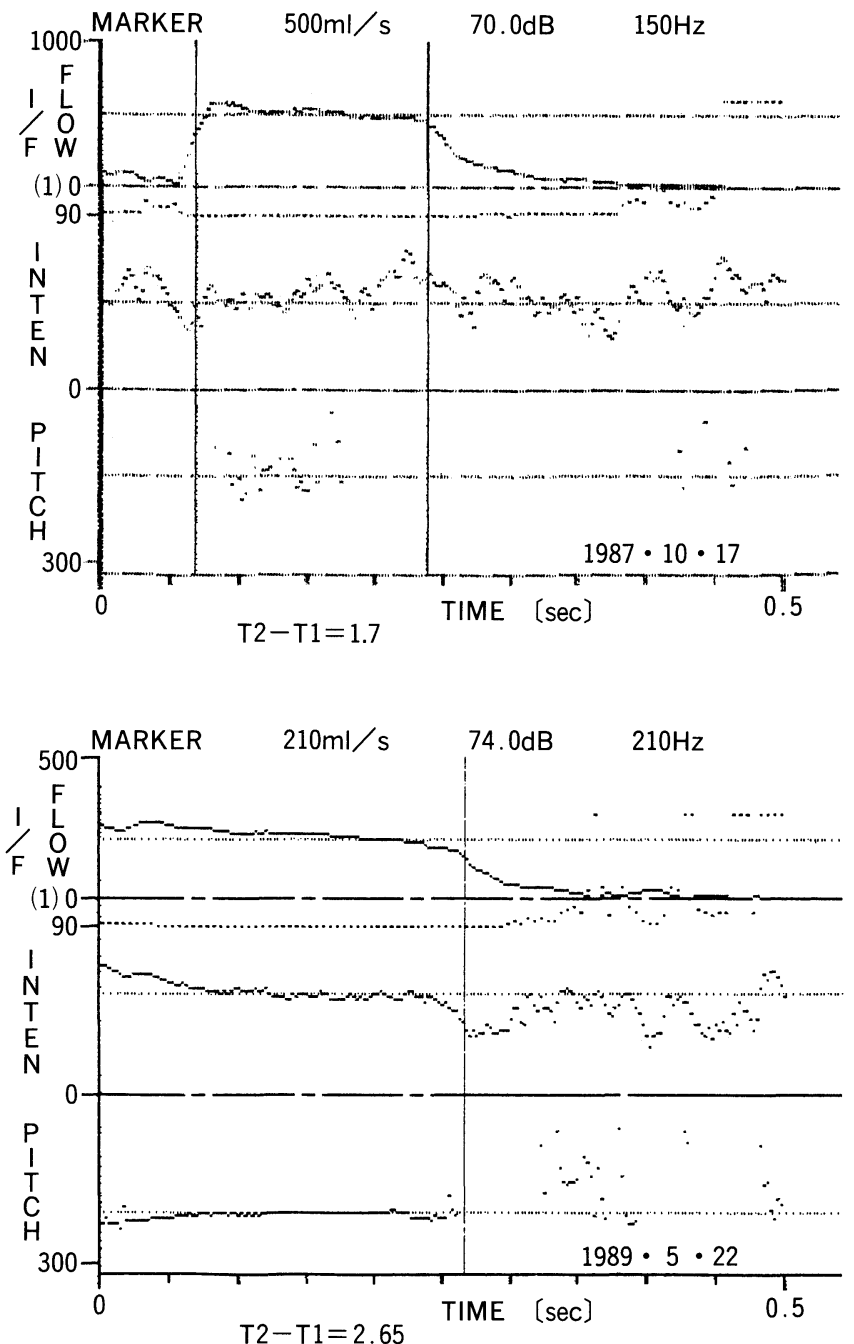

図 3 症例 1 のシリコン注入前後での発声機能の変化. シリコン注入前では音声 の基本周波数が記録されなかったが術後には安定した数值が得られるよう になった.しかし発声持続時間はせいぜい 3 秒であった。 
症例 1 では右前筋が筋電図上，発声動作にと あなう正常の活動を示したととから，はじめは 前筋転位術を予定した，声帯の再運動化を衫ら ったわけである。しかし筋とその周囲組織との 癒着が高度であったため, Isshiki の方法"2によ る披裂軟骨内転術に変更した，手術の主目的が 発声機能の改善にあったからである，結果的に は手術の目的は達せられず，第二，第三の手術 が必要であった。また敢えて声帯内方移動を行 う場合でも，輪状披裂関節に直接の侵襲が拈よ ばない手術法を選択すべきであったと反省して いる，本症例では，わずかの声門間隙でも失声 状態となったために二回のシリコン注入により 声門間隙をなくす必要があった（図 $1-a^{\prime}{ }^{\prime}$ ), シリコン注入前後での発声機能の変化を図 3 に 示す.

症例 2 では，はじめわずかながら喉頭に運動 性を認めたので，経過観察していた。しかしや がて完全固定を来たしたために，術後に嗄声が 増強することについて了解を得たうえで披裂軟 骨摘出術を行った，本症例では術前から両側の 仮声帯が膨隆していて，いわゆる仮声帯発声之 なっていたためか，術後も発声時には仮声帯が 声門を閉鎖している（図 4)。皇れが幸いして 術後音声は，気息性の度合が増強したものの日 常会話に扔いて発声困難が訴えられる程は悪化 しなかった。

症例 3 では，一時は完全に声門閉鎖を来たし

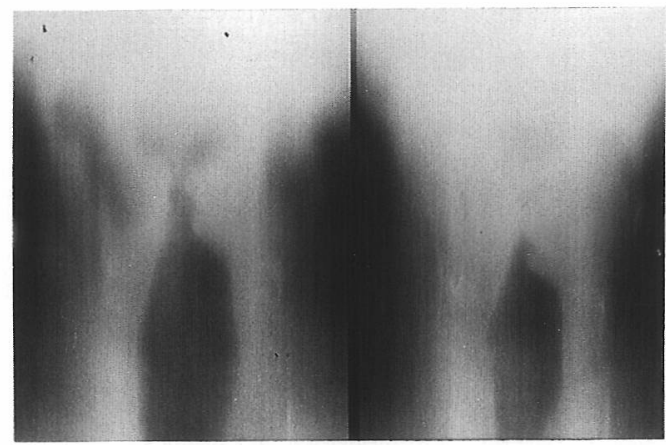

図 4 症例 2 の術後の喉頭断層撮影所見 左が吸気時で右が発声時.
たが，運動性が回復する可能性があり，また術

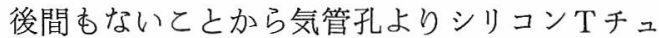
ーブを挿入した状態で退院し，現在外来にて経 過観察中である。しかし Tチューブは栓をしな い状態では内壁に湤皮が付着しやすく, 経鼻呼 吸が全く不能な症例の長期間の気道確保には適 応できないととに留意すべきである，本症例で は完全固定を示した期間が約一週間と短く,や がてわずかながら声門間隙が出現したため，T チューブがからうじて適応できた。

症例 4，5 はいずれも声帯の運動性がわずか 飞保存されていた例である。 とのような例では 労作時呼吸困難むるいは夜間の喘鳴(いびき)が 主症状であることが多い，そのため，はじめに 内科を受診し喘息として治療をうけている例が ある。このような例では発声機能は比較的良好 である，ただし完全固定を来たし呼吸困難が出 現する可能性があるので本人扰よび家族に対す る病状の説明と，慎重な経過観察が重要である。

2 . 文献的考察

反回神経麻㾝を外科的に治療する場合, 喉頭 に非可逆的侵襲をくわえることが多いので，い つまで待って手術すべきかは重要な問題である。 片側麻㾝については多くの症例の経験汃ら，発 症後 3 力月待てば回復するものはそのきざしを 示す3)といわれている。種々の原因による両側 麻痺一般の予後についてはほとんど分かってい ない，特殊な例之しては，安岡ら ${ }^{4)}$ は上気道感 染に続発して出現した反回神経麻痺の長期観察 を行った結果を報告している，それによると両 側麻痺と晾断した 21 例のうち 15 例は 6 力月以内 に回復の兆候が観察され，14年後む両側声帯が 正中位近くに固定され予後不良と判断されたも のは 4 例であったという。初診時に両側声帯が 固定していたのは 2 例のみで，ほとんどは著 者らの分類では『可動性あり』という症例であ った。

両側麻痺の予後については今後も検討されな ければならないが, type 1a の場合は呼吸困難に 対して即座に対応しなければならない，方法 
は声門開大術と気管開空術の二通りある。丘村 ら ${ }^{5)}$ は声門開大術を行った 5 症例を報告し，手 術の基本方針は発声機能をある程度無視しても, 有効な気道確保ができるよう充分な声門間隙を 得ようとすることであるととを力説している. 著者らもこの意見に基本的には賛成であるが， 実際には症例 1 のごとくわずかな声門間隙でも 失声状態を呈する例ああるととから，広戸6）が 報告した気管開空術がより好ましい場合屯ある. どのような例が失声状態となるかについての確 かな予測法は今のところない. 著者らの経験で は呼気時のピークフローが低い場合には, 失声 となる可能性が高いと考えている. わずかな声 門間隙でも，声帯振動を起てすための最低限の 声門下圧がえられないからである. 局所麻酔に て手術を行う場合には内視鏡下に声門を開け， 声帯振動の消失する開大度を直接的に調べるこ とができる.

声門開大術の適応については, 多くの報告で 指摘されているごとく, 呼気時と吸気時との相 互関係から導かれる資料が，声門狭窄の程度や 性質を敏感に反映している，例えば Bogaard ら7) は呼気時と吸気時のフロー・ボリューム曲 線加ら, 画側麻痺の気道状態の変化や, 外科的 治療効果の判定に関して最も有益な資料が得ら れると述べている。 ちなみに上記の 5 症例のフ ロー・ボリューム曲線を図 $5 \mathrm{a}, \mathrm{b}$ に示す。吸 気時と呼気時での測定值の相互関係を表す指標 として例えば, 呼気時と吸気時のピークフロー の比をとってみると, 症例 $1,2,3$ がそれぞ れ0.26，0.44，0.30であったのに対して，症例 4，5ではそれぞれ0.60，0.54であった．すな わち呼吸困難が軽度であった症例では, 呼吸困 難に対してなんらかの処置を余儀なくされた症 例に比べて高值を示した.

両側麻痺では発声機能の改善をめざした外科 的操作すなわち声帯の内方移動術は, 呼吸困難 を出現させる危険をともなう。そのため発声機 能の改善を目的とする外科的治療の報告は少な い。しかしわずかに声門間隙を調整することで
良好な声帯振動がえられかつ呼吸困難む来たさ ないということはありうる。また実際にそのよ うな報告8) がなされている。両側麻痺にともな う発声障害は極めて高度であることが多いため， 発声機能の改善を目的とした治療の確立む今後 の大きな課題であると考えられる.

麻痄声帯の再運動化を図る, いわゆる動的再 建法は特に両側麻㿁に対しては理想的な治療で あり Iwamura ${ }^{9)}$, Miglets ${ }^{10)}$ るいは Tucker ${ }^{11)}$ の報告以来, 多くの実験的かつ臨床的研究がな されている。しかし残念ながらまだ一般的に用 いられるには至っていない.

\section{F-V CURVE}

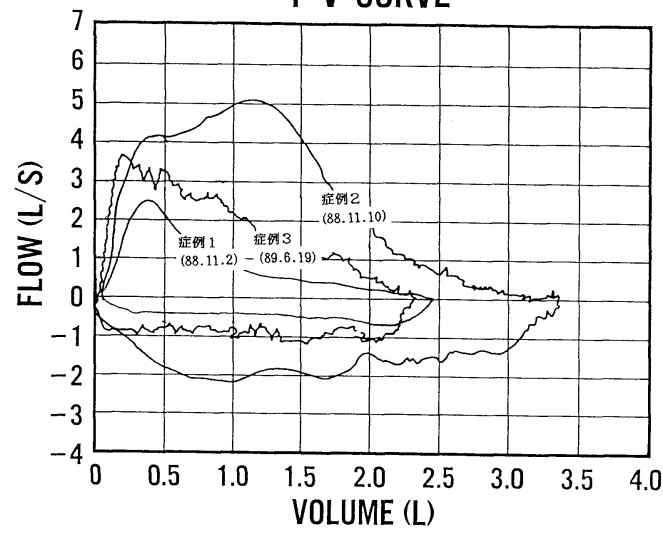

図 5 a 安静時呼吸困難のあった症例

\section{F-V CURVE}

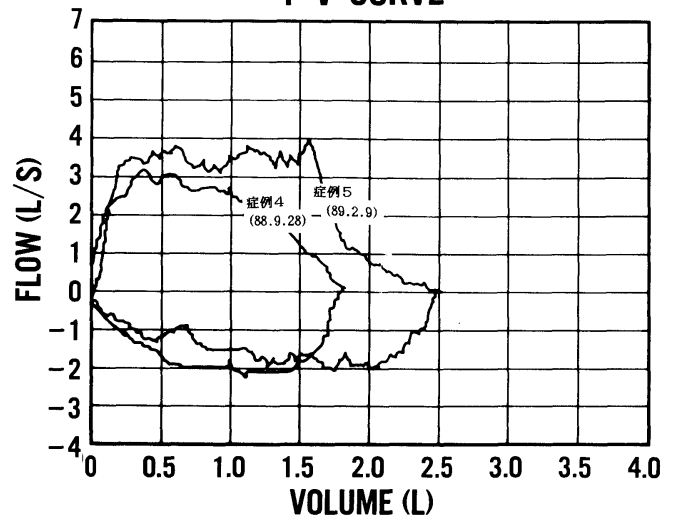

図 $5 \mathrm{~b}$ 呼吸困難は軽度であった症例 


\section{まとめ}

1. 両側麻痺は二型に大別される。正中位 固定型と非正中位固定型の二型である，声帯に 弓状変化があるかないかでそれぞれ亜型に分け られる. 内視鏡的に可動性が認められる場合に は『わずかに可動性あり』と付記する，正中位 固定型では呼吸困難が，また非正中位固定型で は失声および誤燕が主症状となることが多い。 両側麻痺ではどちらかの声帯の運動性がわずか であ保存されている例では，完全に固定してい る例に比べて，症状ははるかに軽い，しかし急 に完全固定に移行する場合があるので，患者お よび家族に対する注意と慎重な経過観察が必要 である。

2.画側麻痺の治療では，当然のととながら， その目的とそれにとあなって生じる機能障害を 患者に充分説明し，症例でとに最善の方法を選 択すべきである。両側麻痺に伴う発声障害につ いては従来あまり注意がはらわれていなかった が，患者が発声機能の保存または回復をつよく 望む場合があり，発声機能の改善を目的とした 治療法の確立も今後の大きな課題である.

本論文の要旨は第70回日本耳鼻咽喉科学会東京都地 方部会 (平成元年 1 月28日, 東京) および第14回音声 外科懇話会（平成元年 6 月 3 日，東京）において発表 した.

\section{文献}

1) Commings CW, Sessions DG, Weymuller EA, et al : Arytenoidectomy ; Midline thyrotomy approach. Atlas of laryngeal surgery. pp 64 71,
The CV Mosby Company, ST Louis Toronto, 1984.

2) Isshiki N, Tanabe $\mathrm{M}$ and Sawada $\mathrm{M}$ : Arytenoid adduction for unilateral vocal cord paralysis. Arch Otolaryngol 104 : 555 558, 1978.

3 ）岩村 忍：喉頭運動障害の診断一治療方針の決定 をめぐって一，日気食会報 $37: 115 \sim 120 ， 1986$.

4 ）安岡義人, 伊藤文英, 松崎充男, 他 : 1970年流行 した声帯麻痺症例の長期観察一両側声带麻痺例を 中心に一. 日気食会報 $36: 435 \sim 441 ， 1985$.

5 ）丘村 熙, 湯本英二, 佐々木裕美, 他 : 両側反回 神経麻痺における声門開大術後の呼吸機能につい て. 耳鼻臨床 $76: 2505 \sim 2513 ， 1983$.

6 ）広戸幾一郎：両側後筋麻痺の手術的療法. 日耳鼻 $68: 1460 \sim 1465,1965$.

7) Bogaard JM, Pauw KH, Verspille A, et al : Maximal expiratory and inspiratory flow-volume curves in bilateral vocal cord paralysis. ORL $49: 35$ $\sim 41,1987$.

8 ）牛嶋達次郎, 坊野 馨, 加瀬康弘, 他：両側反回 神経麻痺に対する声帯内シリコン注入術の一例. 音声言語 $30: 72 \sim 73,1989$.

9 ) Iwamura $S:$ Functioning remobilization of the paralyzed vocal cord in dogs. Arch Otolaryngol $100: 122 \sim 129,1974$.

10) Miglets AW : Functional laryngeal abduction following reimplantation of the recurrent laryngeal nerves. Laryngoscope 84 : 1996 2005, 1974

11) Tucker HM : Human laryngeal reinnervation. Laryngoscope $86: 769 \sim 779,1976$.

$\left(\begin{array}{l}\text { 原稿受付 : 平成元年 } 7 \text { 月 } 26 \text { 日 } \\ \text { 原稿採択 : 平成元年10月19日 } \\ \text { 別刷請求先 : 渋沢三伸 } \\ \text { 个113 東京都文京区湯島 } 1-5-45 \\ \text { 東京医科歯科大学難治疾患研究所 } \\ \text { 神経疾患研究部門 }\end{array}\right)$

